\title{
Faces of Modernity in the Architecture of the Peronist State, 1943-1955
}

\author{
Anahi Ballent \\ University of Quilmes / CONICET \\ aballent@unq.edu.ar
}

\begin{abstract}
Within the context of Peronist expectations regarding culture, the article examines three cases of architectural and urban projects that displayed various kinds of articulation in terms of promotional policies, state institutions, intervening technology, the urban aspects involved, and the architectural aesthetics proposed. The works are interpreted - with respect to their aesthetic forms and images and the political content they transmit - as materializations of the new order envisaged by Peronism. Each of the case studies highlights different visualizations or aspects of this new order. In conceptual terms, all of the characteristics manifested by Peronist cultural production were also observable in the projects of inter-war dictatorships, especially those of Italian fascism. Clearly, given the period in which Peronism came to power, it is anachronistic to locate the architectural programmes which it hosted within the political categories of 'inter-war dictatorship' or even 'fascism'. Nevertheless, seen through the lens of these two categories, it can be shown that the ethos of Peronism falls within the framework of the fascist era, due to its promotion of grandiose visionary projects for national renewal expressed through the transformation of the built environment on a scale characteristic of the two fascist regimes. Such projects mythically elevated Perón and Eva Perón to the level of leaders of the Argentinian people, whom they both saw as an organic entity, socially harmonious, rooted in the history of the nation and, in international terms, decidedly placed the nation on the road to the "third position" pioneered by fascist movements before 1945 in which tradition and modernity were reconciled in a form of modernism termed by Roger Griffin 'rooted modernism'.
\end{abstract}

(C) BALLENT, 2018 | DOI 10.1163/22116257-00701005

This is an open access article distributed under the terms of the prevailing CC-BY-NC License at the time of publication. 


\section{Keywords}

Argentinia - architecture - urbanism - esthetics and politics - Peronism modernism - fascism

\section{Peronism and Fascism}

Juan Domingo Perón was elected President of the Argentine Republic in 1946 and overthrown in a military coup in 1955 . His rise within the state began during the military government in power between 1943 and 1946, the so-called June Revolution. During this time, he also laid the foundations for the political movement that he would come to lead, called Justicialism to suggest that its core motivation was the defence of social justice. As is well known, Perón admired Italian Fascism and was directly acquainted with it, having lived in Italy as a military attaché from 1939 to 1941. His government included staff whose affinity with Nazism was public knowledge (an example is General Juan Pistarini), as well as intellectuals who had participated in dictatorial governments, such as the Spanish statistician José Figuerola, a collaborator of Miguel Primo de Rivera before coming to Argentina. Nevertheless, it is essential to remember that Peronism came to power after the Second World War, a time in which the climate was not very favorable to explicit appeals to fascist ideals as political references. Although a number of key notions from the ideology of Peronism, such as anti-liberalism, nationalism, corporatism and the quest for a new society based on a 'third position' between liberalism and communism had been present in the ideologies of inter-war dictatorships, these took on new meaning in the international climate of ideas after World War II, as well as in a national political scene which Peronism dominated but whichin contrast to inter-war dictatorships-it had to share its political space with other ideological forces.

Despite these differences, which are patently evident from a present-day perspective, Peronism was labelled, from its very inception, 'fascism' by a vast section of the political opposition. Perhaps as a consequence of the acrimonious nature of the debate conducted during the 1940s and 1950s, Argentinian political historiography has sought to distance itself from the conceptualisation of Peronism as a form of fascism, preferring instead to include it within the typology of 'populism.' Nevertheless recently, some works have revisited the

1 On the categorization of Peronism as a form of populism, understood as a form of social democratization, and given renewed impetus by the work of Ernesto Laclau, On Populist 
link between fascism in Italy and Argentina from a fresh perspective, namely in terms of transnational history. Federico Finchelstein considers fascism to be a generic and transnational ideology, susceptible of interpretations or adaptations beyond Mussolini's original vision, and from this perspective, it acquires new significance as a factor influencing in the formation of Peronism and its political culture. ${ }^{2}$

As a result, it now seems a good moment to re-explore certain features of Peronism which linked it to European fascisms, especially those of with a developed programme of cultural renewal, as they may reveal aspects of Peronism and its relation with the state that seem to go beyond its populist characteristics. We are referring specifically to those core aspects identified by Roger Griffin in relation to the right-wing dictatorships of the interwar period, which he presents in a paper included in this issue: namely, the orientation towards the future (which has allowed him to characterise them as forms of "programmatic modernism"), and the tendency towards a palingenetic transformation of society. ${ }^{3}$

Approached from this angle, architecture and urban planning prove to be particularly relevant subjects for historical analysis. They were areas in which the regime advanced its projects for the transformation of society, through what it called 'great achievements' in the cultural domain. Proactive city planning, new public buildings, and ambitious housing policies caused a positive set of images associated with Peronist politics to be disseminated, despite the fact that the activity lacked unity and coherence in terms of style or aesthetics.

Reason (London: Verso, 2005), see, among others, Matthew B. Karush and Oscar Chamosa, ed., A New Cultural History of Peronism: Power and Identity in Mid-Twentieth Century Argentina (Durham: Duke University Press, 2010), and Ernesto Semán, Ambassadors of the Working Class: Argentina's International Labor Activists and Cold War Democracy in the America (Durham: Duke University Press, 2017). The impact of redistributive policies is another aspect considered as marking a difference between fascism and Peronism. See Juan Carlos Torre and Elisa Pastoriza, 'La democratización del bienestar (1945-1955),' in Los años peronistas 1943-1955, Nueva Historia Argentina, Vol. 8, ed. Juan Carlos Torre (Buenos Aires: Sudamericana, 2002 ), 257-313.

2 Federico Finchelstein, Transatlantic Fascism: Ideology, Violence, and the Sacred in Argentina and Italy, 1919-1945 (Durham: Duke University Press, 2010). A wider perspective can be seen in a recent work by the same author: From Fascism to Populism in History (Oakland, California: University of California Press, 2017).

3 See also Roger Griffin, Modernism and Fascism: The Sense of a Beginning under Mussolini and Hitler (Basingstoke: Palgrave Macmillan, 2007). 
The first studies in the History of Architecture dedicated to the architectural production of the period were carried out during the 196os. These followed the established formula of that time, which equated modernist aesthetics with democratic policies, and vernacular or classicist aesthetics with dictatorships and 'reaction', which associated Peronist urbanism with the latter. During the 1980s, however, studies demonstrated the modernist component in Peronist cultural production, and opened the way to broader reflection on the regime's aesthetic diversity and its significance in terms of politics. ${ }^{4}$ Such reflection led to the recognition of greater complexity in the interpretations of the links between techniques (architecture and urban planning as disciplines), aesthetics and politics under Peronism. ${ }^{5}$

For this line of thinking, particular significance is assumed by the working hypothesis put forward by Manfredo Tafuri in his well-known 1980 essay on the housing policies of socialist Vienna: that the relationship which ideologies and architectural languages form with politics is a tangential one. ${ }^{6}$ In other words, both are independent entities and are far from being homogeneous within themselves; they may connect at one point but produce histories that are different prior to and after that point. Politics, then, neither creates nor directly produces architectural forms or aesthetics, and in any case, its links to them can occur in a variety of ways. Tafuri adds another variable that affects this relationship, making it more complex: the urban context, which conditions projects and policy through its materiality, its history and its traditions. In short, the relationship between aesthetics and politics is not a direct link, but rather one that is mediated by diverse factors: fundamentally the urban context in which the architecture is situated, as well as the technical aspects through which it is conceived, aspects that are relatively autonomous.

4 Pedro Sondereger, Arquitectura y Modernidad en la Argentina (Buenos Aires: CESCA, 1986), María Isabel de Larrañaga and Alberto Petrina, 'Arquitectura de masas en la Argentina (1945-1955): hacia la búsqueda de una expresión propia', Anales del Instituto de Arte Americano 25 (1987): 107-115.

5 Jorge Francisco Liernur, Arquitectura en la Argentina del siglo Xx: La construcción de la modernidad (Buenos Aires: Fondo Nacional de las Artes, 2001); Rosa Aboy, Viviendas para el pueblo: Espacio urbano y sociabilidad en el barrio Los Perales, 1946-1955 (Buenos Aires: Fondo de Cultura Económica: 2005); Anahi Ballent, Las huellas de la política: Vivienda, ciudad, peronismo en Buenos Aires, 1943-1955 (Buenos Aires: Universidad Nacional de Quilmes / Prometeo 3010, 2005), Mark Healey, The Ruins of the New Argentina: Peronism and the Remaking of San Juan after the 1944 Earthquake (Durham: Duke University Press, 2011).

6 Manfredo Tafuri, Vienna Rossa: La política residenziale nella Vienna socialista (Milano: Electa, 1995, first published 1980), 7 . 
These observations provide the main orientation for this article. Firstly, we will analyse the realization of Perón's projects in the cultural domain, which will shed light on the conditions of architectural production and urban planning promoted by the state, while at the same time allowing us to consider the political climate within which the experts formulated their projects. Secondly, we will examine three cases of architectural and urban intervention undertaken by the Peronist which demonstrate different articulations between promotional policy, state institutions, technological innovation, particular urban conditions and the aesthetics proposed. The various roles played by all of these factors contribute to the understanding of Peronism as a phenomenon that transformed Argentine politics and society in a decisive but heterogeneous way.

\section{‘Towards Great Achievements': Perón and Cultural Production}

In November of 1947, during the initial stage of his administration, Perón held a series of meetings with intellectuals, artists and educators, the aim of which was to approach the 'question of culture in an integrated way'. ${ }^{7}$ In these meetings, he made it clear that the bases of the revolution that his government intended were founded on reforms covering the social, economic, and political domains, in that order. He stated nevertheless that other areas remained to be consolidated, ones that he considered to be the true underlying work, the work of creation that needs to be realized in order for things to transcend the passing of time, so that people don't forget about us in a few years'. By this, he was referring to the reform of justice, public instruction, and culture, in that order. ${ }^{8} \mathrm{He}$ understood the latter to mean Arts (including architecture and urban planning) and Letters, which were under the jurisdiction of the Ministry of Education, while radio and the cinema were within the sphere of the Subsecretary (later the Secretary) of Information, an organ of state responsible for political propaganda.

In order to advance cultural reform, Perón proposed the establishment of a more comprehensive state body that would group intellectuals, artists and educators and sponsor their activities and creations. Each area of production would constitute a unique association, incorporated within the organ that directed culture in all of its aspects, a structure reminiscent of similar state departments directing cultural production in Nazi Germany and Bolshevik

7 [Juan Domingo Perón] El Presidente de la Nación Argentina Gral: Juan Perón se dirige a los intelectuales, escritores, artistas pintores, maestros (Buenos Aires: n.d.), 42.

8 Perón, El Presidente de la Nación Argentina Gral, 43. 
Russia, though considerably less totalitarian and propagandistic in ethos and prupose. The key to its success lay in applying to society the 'science of organization', the importance of which he professed to have observed in (Fascist) Italy. Such a science would allow for the overcoming of the 'state of disorganization and disorder in which we have lived until now'. ${ }^{9}$ Perón was aware that the proposal could lead to his mentors being considered 'dictators', and awaken the notion that they meant to 'have people march to the beat with rifles on their shoulders, standardizing criteria and ideas.' ${ }^{10}$

He responded as follows to such objections: 'That's not what it's about. The idea is to organize our strengths in order to achieve the best results for the least amount of sacrifice and to organize our culture so that we avoid continuing to entrench in our country things that are contrary to our idiosyncrasy, our race, our religion and our language, but instead instill and impose our own culture.'11 This building of 'our own culture' was a task assigned to intellectuals and artists, while the state limited itself to providing an institutional framework. Indeed, Perón affirmed: 'as a representative of the state, I can offer you just one thing: state action, by which I mean organization and means. The rest must come from you, the people..12 This appeal was broad and did not require political affiliation or predetermined aesthetic or ideological choices: 'Anyone who wishes to perform a constructive task ... will be welcomed, and if he's right, we will of course go along with him because the result of this struggle, this discourse, must be what is most beneficial for the nation.13

At the same time, he announced the construction of the 'citadel of the humanities' in the city of Buenos Aires, which would be an arts and culture cluster performance spaces, arts academies, schools for the fine and applied arts, museums, and exhibition galleries. 'The Museum of Fine Arts is already planned. It might possibly be built in the center of this great citadel, which will contain facilities for the humanities, philosophy and letters, architecture, urban planning and all cultural groups.1 ${ }^{14}$ This was a demonstration of the major state investments he promised in order to foster cultural production: 'Until now, our country has been feverish with achieving small things, and my wish is to make it feverish to achieve great things.'. ${ }^{15}$

\begin{tabular}{ll}
\hline 9 & Ibid., 21. \\
10 & Ibid. \\
11 & Ibid. \\
12 & Ibid., 49. \\
13 & Ibid., 54. \\
14 & Ibid. \\
15 & Ibid., 50.
\end{tabular}


The pronouncements of Perón in this series of consultations provide a summary of the ambitions for a cultural renaissance which he had during the first years of his administration. These were centered on co-partnering with cultural producers via their organization within the state, with the aim of building and disseminating a culture based on key ideologies of nationalism, using Italian Fascism as a reference point. As the promotor of 'great achievements', the state would not impose aesthetic or thematic goals, leaving the identification of these to emerge from debate among intellectuals and artists.

Various state entities were created within the Ministry of Education, such as the Sub-secretariat of Culture, the National Culture Commission and the National Committee of Intellectuals, and a number of groups of intellectuals and artists were formed that openly supported the government. However, Perón did not find the broad support he had expected. This was because, firstly, despite his pluralistic discourse, he was seen as surrounded by intellectuals who came out of a strain of nationalism that was particularly Catholic, and these were not always the most prestigious or original in cultural terms. Furthermore, this proximity to Catholic and nationalist elites led to charges that his policies favoured certain ideological and aesthetic choices over others within the area of culture. Secondly, the cultural domain was splintered by political conflicts such as the one generated by Perón's political ascent, especially the tumultuous election of 1946 in which he won the presidency. Previously, from 1936 onward, and especially during World War II, the majority of intellectuals and artists had aligned themselves with fronts involved in the struggle against fascism. Any integral proposal for the promotion of culture by the state was therefore suspected of being an attempt to control creative output and restrict the autonomy of leftist thinkers and artists.

The citadel of the humanities was never built. From 1950 onward, the economic crisis obliged the government to reconsider the use of resources that had been destined for state organs sponsoring cultural production. As Flavia Fiorucci has demonstrated, resources went to cultural diffusion rather than cultural production, so much work was done for increasing cultural consumption and democratizing access to cultural events, while plans for organizing producers through state intervention were never fulfilled. ${ }^{16}$ Meanwhile, in about 1950, the regime emphasized its authoritarian features, and political propaganda became increasingly focused on Perón and Eva as leaders. The regime attempted the organization of intellectuals and artists once again in 1954, this time following a union model with the creation of the General

16 Flavia Fiorucci, Intelectuales y peronismo 1945-1955 (Buenos Aires: Biblos, 2011). 
Confederation of Professionals. This organization, which received significant criticism from the opposition, lasted for only two years, until Peronism was overthrown by a coup in $1955 .^{17}$

These events demonstrated the difficulties faced by an authoritarian government with great ambitions in terms of the national renaissance it aspired to bring about, once it attempted to use state institutions to co-ordinate cultural production and inspire the creative elites responsible for it in a post-war world, still using models derived from fascism and from the historical period prior to its accession to power. At the same time, we see that Perón did not attempt to impose aesthetic guidelines for cultural production in an authoritarian spirit, as could be observed in various areas of production, such as painting and the cinema. ${ }^{18}$ Nevertheless, various incidents of conflict were noted between authorities and representatives of certain artistic tendencies, there were cases of censorship, and self-censorship was common among those who hoped to receive some kind of state support. The 'Peronization' of society and the state, present since the beginning of the administration and more intense after 1950, caused an atmosphere of constant pressure for cultural production that operated in various ways, directly in some cases and more surreptitiously in others.

Not many distinguished architects gave the government their explicit political support. However, the new and proactive policies for public works were indeed a powerful attraction which they did not ignore, even though the proposed projects did not have the integral nature that Perón had hoped for. As has been stated, and as we have just observed concerning other areas of production, no single policy-related aesthetic was applied within the area of architecture and urban interventions. Architectural production adopted forms within a range that included radical modernist, moderate modernist, rustic/ vernacular, and classical. As we have said, this was due to the fact that the state did not impose any particular criteria or aesthetic, but also to Peronism's lack of ideological unity, and to the presence of different technical teams working within the state structure.

This variety does not mean that relationships between architecture and politics do not exist; on the contrary, images of architecture and the city were

17 Ezequiel Adamovsky, 'El régimen peronista y la Confederación Nacional de Profesionales: Orígenes intelectuales e itinerario de un proyecto frustrado (1953-1955), Desarrollo Económico 182 (2006): 245-265.

18 On painting, see Andrea Giunta, Vanguardia, internacionalismo y política (Buenos Aires: Paidós, 2002); on the cinema, see Clara Kriger, Cine y peronismo: El Estado en acción (Buenos Aires: Siglo XXI, 2009). 
the objects of an intense publicity campaign, and contributed to the creation of collective myths about contemporary history, and to the establishment of Peronism's political identity. All projects, regardless of how they were distributed to different departments within the state or which of the technical teams promoted them, were always capitalized upon politically. Perón cumple [Perón comes through] was the slogan repeated on every sign at a public works project throughout the entire nation. So Marla Stone's concept of hegemonic pluralism, which she used in relation to Italian fascism, applies as well to Peronist architecture. ${ }^{19}$ What follows is a case study in three strikingly different aesthetics used in state-sponsored projects to generate a sense that Argentina was moving under Peronism into a new national future and embracing modernity in an ordered, collective, communal spirit, while avoiding the radicalism and destructiveness of Nazism or Bolshevism.

\section{A Modernism Rooted in Tradition: The Ministry of Public Works and 'Ministro Pistarini' Airport in Ezeiza}

During the government of the June Revolution of 1943, when Perón was the nation's Vice President, it was decided to provide the city of Buenos Aires with a modern airport, according to the needs of the time. The topic had been debated in Congress, and studies had been done during the previous decade, but no concrete action for the airport's construction had resulted. The choice of the site and the project itself were the responsibilities of the Ministry of Public Works, a national organ created in 1898 and possessed of a solid technical bureaucracy, made up primarily of engineers and including a smaller group of architects. Leading this Ministry was General Juan Pistarini, who continued in the position as an active collaborator with Perón as part of the second line of the Peronist government until 1952. This military engineer, a known Nazi sympathizer, had joined the ranks of the Catholic Nationalist wing of the army

19 The concept is defined by Stone as 'a Gramscian-informed notion describing the semblance of pluralism that coexists within and gives legitimacy to a repressive regime. Hegemonic pluralism was the acceptance, appropriation and mobilization of a variety of aesthetic languages in the pursuit of consent and legitimation and in the search for a representational language evocative of the Fascist new era'. Marla Susan Stone, The Patron State: Culture and Politics in Fascist Italy (Princeton: Princeton University Press, 1998), 65. On the absence of an imposed, particular aesthetic, see also Giorgio Ciucci, Gli architettie il fascism: Architettura e cittá 1922-1944 (Torino: Einaudi, 1989), and Emilio Gentile, Il culto del littorio: La sacralizzazione de la política nell' Italia fascista (Roma-Bari: Laterza, 1993). 
in the 1930s. This group was one of the principal contributors to the building of Perón's political image and one from which a large part of the ideas of Peronism came. ${ }^{20}$

He led a ministry which existed in an extreme state of tension with the previously established professional bureaucracy. With what he considered to be a heroic spirit, he strengthened an executive apparatus, which tended to be rapid and efficient, and also reduced the bureaucracy's decision-making and control powers. For the management of the project, he created a special office under his direct authority: the Committee of Studies and Works for the Buenos Aires Airport. ${ }^{21} \mathrm{He}$ chose for the site a low-lying zone, free of construction, along the Matanzas River and near the town of Ezeiza, about 20 kilometers (12 miles) from the city, in the southwestern part of the metropolitan area that was known as Greater Buenos Aires. ${ }^{22}$ The area expropriated was very large (equal to one-fourth of area of the City of Buenos Aires), a fact that indicates that the airport was thought of as a catalyst for a great suburban transformation. ${ }^{23}$ Indeed, the initial operation consisted not only of the airport and the freeway connecting it to the city (the first in the country), but included as well a group of dwellings for airport personnel (the 'Aeropuerto' neighborhood), forestation of the area (the so-called 'Ezeiza Woods') and numerous workingclass recreation areas, such as the enormous swimming pools located near the river. $^{24}$

20 On Pistarini, see Anahi Ballent, 'Juan Pistarini. Soldado, ingeniero, ministro: un constructor de paisajes políticos,' in La segunda línea: Liderazgo peronista 1945-1955, ed. Raanan Rein and Claudio Panella (Buenos Aires: Untref / Pueblo heredero, 2013), 289-312. On Catholics in the government of Peronism, see Loris Zanatta, Del estado liberal a la nación católica: Iglesia y Ejército en los orígenes del peronismo 1930-1943 (Buenos Aires: Universidad Nacional de Quilmes, 1996), and Loris Zanatta, Perón y el mito de la nación católic: Iglesia y Ejército en los orígenes del peronismo 1943-1946 (Buenos Aires: Sudamericana, 1999).

21 'Architecture of the Peronist State 1943-1955', accessed February 26, 2018, http://architec tureperonism.tumblr.com/, fig. 1.

22 According to the 1947 Census, the City of Buenos Aires had a population of nearly three million within its administrative limits, while Greater Buenos Aires (25 partidos) had 1.800.00o inhabitants. Margarita Gutman and Jorge Enrique Hardoy, Buenos Aires 1536-2006: Historia urbana del Área Metropolitana (Buenos Aires: Infinito, 2007), 334.

23 Decreto 29.966/1944 and 4.020/1945.

24 On the Project, see Ministerio de Obras Públicas, Labor realizada y en ejecución: Breve reseña 1943-1947 (Buenos Aires: Kraft, 1947). 


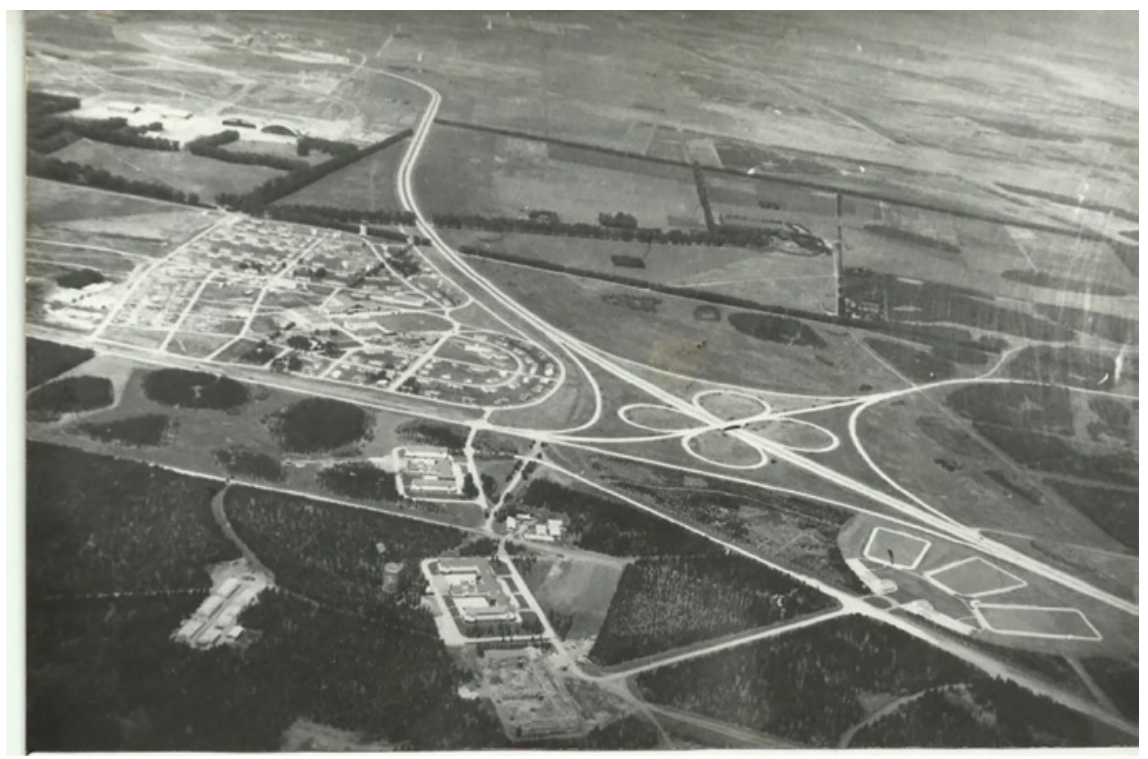

FIGURE 1 Suburban landscape, Ezeiza. Freeway, housing and social programs. SOURCE: ARCHIVO GENERAL DE LA NACIÓN, SECCIÓN DOCUMENTOS GRÁFICOS

Other state and public organizations saw this new suburban area, and the manner in which the Ministry of Public Works had laid it out, as an environment particularly suitable for realizing their own social welfare initiatives. These included various vacation colonies built by the Eva Perón Foundation as well as their Children's City, which was never built; the housing towers erected by the National Mortgage Bank; and the Olympic Village, a complex for formalized sports activities, created by the Sports Secretariat. So under the direction of the Ministry of Public Works, construction in the area became a collective work in which various social programs found a space in which to develop.

In 1948 the Ministry began construction on what would be the government's largest housing undertaking: Ciudad Evita, which was projected to be a grouping of five thousand units. Commenting on it, one of the most important diffusion publications for government works affirmed that 'this undertaking alone (was) sufficient to give the government of General Perón its rightful place in history.'.25

In this area, then, technical and economic modernization projects went hand in hand with schemes for social modernization, and the architecture

25 Control de Estado de la Presidencia de la Nación, La Nación Argentina, Justa, Libre y Soberana (Buenos Aires: Peuser, 1950), 313. 
erected there comprised a great formal contrast that arose out of these two dynamics of the operation. Aesthetic modernism dominated the stretch of freeway and the airport buildings, while rustic forms and the so-called 'California Style' prevailed in the dwellings under the Housing Office of the Ministry of Public Works. ${ }^{26}$ In other words, buildings which were public and of a highly technological nature took on an aesthetic which contrasted sharply with that of programs devoted to working-class domestic life or leisure.

The airport buildings (terminal, customs facility and hotel) comprised a symmetrical group of stark, prismatic blocks. These were conceived in a nonradical modernism with a notable presence of modern construction materials and technologies, as is the case with the great wall of glass that forms the rear of the terminal. In general terms, this was an architectural tendency that had been applied in numerous divisions of the state ever since the previous decade. Within the context of airport architecture, it was in keeping with contemporary examples considered to be reference points or models, such as Washington National Airport. In some cases, the Buenos Aires facility has been qualified as a 'monumentalist' work (a term often applied to broad sectors of public architecture of the 1930 s and 40s). Yet strictly speaking, the architecture does not possess, in terms of form, size or proportions, characteristics that warrant such a denomination, one that, as we will see later, can be applied more accurately to other examples of architecture from the period.

The housing complexes were comprised of individual dwellings of the chalet style, with gabled roofs of Spanish-styled tiles and brick walls painted white with wood details. This rustic language came to be called 'California Style', a term referring to what in the U.s. was called 'Mission Style.' This was an architectural aesthetic developed since the end of the nineteenth century on the west coast of that country, one that sought to construct images capable of identifying the region by recreating in modern fashion architectural forms that had accompanied its initial colonization. Under different names, this vaguely Spanish aesthetic has been adopted in many Latin American countries as one appropriate to the climate, methods of construction, culture and local traditions. We should emphasize that, strictly speaking, this was not a vernacular aesthetic, since its intent was not to develop the region's own traditions precisely; rather, it was the result of a typically modern operation of cultural importation. Something similar can be said for the floorplans of the units, which had modern room distribution and were equipped with all the technology of the time.

26 'Architecture of the Peronist State 1943-1955', accessed February 26, 2018, http://architec tureperonism.tumblr.com/, fig. 3 . 
These were forms which diffusely evoked national traditions (more invented than authentic), but did not renounce modernization.

Although its large-scale application to public housing projects was a novelty, the California Style had seen extended use in the suburban, week-end and summer homes of the upper and middle classes during the 1920 and 30 . The style had also been developed somewhat in state works of the same period, in low-cost buildings in Argentina's interior (barracks, hospitals, schools, etc.). In 1934, while heading the Office of Engineers of the Ministry of War, Pistarini had promoted the construction of the Sergeant Cabral Quarters for Sub-officials. ${ }^{27}$ This served as a direct model for projects undertaken later under the Ministry of Public Works. Indeed, the Airport housing complex in Ezeiza repeated the groupings of the chalets with yards, dominated by the volume of the church across from the central square.

The Ciudad Evita project was a special case, because the number of homes required a complex urban plan. It was executed by Luigi Piccinato, a prominent Italian architect and urban designer during the fascist period, who had arrived in Argentina in 1948 along with other colleagues from Italy, and who remained in Argentina until 1950. ${ }^{28} \mathrm{He}$ had been the planner for Sabaudia, one of the new cities built by Mussolini as part of the cleaning up of the Agro Pontino. He was able to apply his experience to Ciudad Evita in terms of its planning and by renovating and elaborating upon the urban tradition of the garden city. However, in contrast to his Italian works of a modernist aesthetic, the Argentine project adopted the California Style, which the Ministry promoted throughout the country as a kind of identifying stamp for government works, applying it to various types of buildings.

One of the complex's relevant aspects is the number of housing typologies of which it was composed. Larger, two-story homes occupy the external lots of the complex, while more modest ones, along with housing tower blocks, are located in its interior. Therefore, the same complex is capable of housing people of various economic levels. Pistarini moved his family to one of the old, existing residences in the expropriated area, and he also planned a neighborhood for ministers of the Executive Branch. These examples show that the area was not considered to be exclusively for the middle or working classes; rather,

27 'Barrio de Suboficiales Sargento Cabral,' Revista de Arquitectura 195 (1937): 99-120.

28 Jorge Francisco Liernur, 'Piccinato, Luigi,' in Diccionario de Arquitectura en Argentina, Tomo O-R, ed. Jorge Francisco Liernur and Fernando Aliata (Buenos Aires: AgEA, 2004), 66-67. Jorge Francisco Liernur, 'Architetti italiani nel secondo doppo-guerra nel dibattito architettonico della nuova Argentina 1947-1951,' Metamorfosi 25-26 (1995): 71-80. 
it was one shared by various social sectors, though it respected differences and hierarchies.

State action, then, created in Ezeiza a green, low-density suburban area in which products of modern technology (the airport terminal, hangers and freeways) were harmoniously integrated with spaces for daily and domestic life. The ministry was a builder of what Martin Warnke, borrowing an expression from nineteenth-century painting, called 'political landscapes', scenes in which natural and artificial elements are articulated with recognizable marks of the policies that had driven them. ${ }^{29}$ In this sense, it was a promise of the future akin to the one that Perón announced in philosophical terms in his 1949 La comunidad organizada [The Organized Community] speech, which became one of the principal pieces of Peronist doctrine. ${ }^{30}$ In it, he set forth his thirdposition theory, championing an ordered society based on solidarity rather than the class struggle, in which a collectivism might unfold that respected the individual, along with economic and technical progress that were tempered by social justice. At the same time, the coexistence of architectural aesthetics within the same project-modernism as a symbol of the future and rustic forms as an allusion to tradition-demonstrated the attempt to conceive a modernism that renounced any 'shock of the new' and created the impression of being anchored in the nation's past, or at least in a generically Latin American past, and thus can be seen as a moderate variant what Roger Griffin's essay terms 'rooted modernism'.

\section{A Radical Modernism: The Buenos Aires of the Estudio para el Plan de Buenos Aires (EPBA) $)^{31}$}

When he assumed power, Perón named Emilio P. Siri as Mayor of the City of Buenos Aires. Siri was a figure who came out of the Unión Civica Radical Junta Renovadora [Renovating Junta of the Civic Radical Union], a political group who had backed Perón in the 1946 elections, distancing itself from

29 Martin Warnke, Political Landscape: The Art History of Nature (Cambridge, MA: Harvard University Press, 1995).

30 Juan Domingo Perón, La Comunidad Organizada (Buenos Aires: Instituto Nacional 'Juan Domingo Perón', 2006). Speech given in Mendoza on March 30, 1949 at the inauguration of the First Argentine Conference on Philosophy. Available at 'Instituto Nacional Juan Domingo Perón', accessed February 7, 2016, http://jdperon.gov.ar/institucional/cuadernos/ Cuadernillo6.pdf.

$31 \quad$ Study for the Plan of Buenos Aires. 
the opposing Unión Cívica Radical [Civic Radical Union], a party founded at the end of the nineteenth century and with a long political history. Siri included in his governing body various members of the Fuerza de Orientación Radical de la Joven Argentina [FORJA: Force for Radical Orientation of Young Argentina], an intellectual political group formed in 1935 within the Civic Radical Union. FORJA was a renovation of the political force based on the revindication of the figure of Hipólito Yrigoyen, the first president belonging to that political body (1916-1922 and 1928-1930), as well as on the elaboration of nationalist and antiimperialist ideas. Splitting off from the main party in 1940, FORJA voluntarily dissolved itself eventually in order to join the political coalition that brought Perón to power. ${ }^{32}$

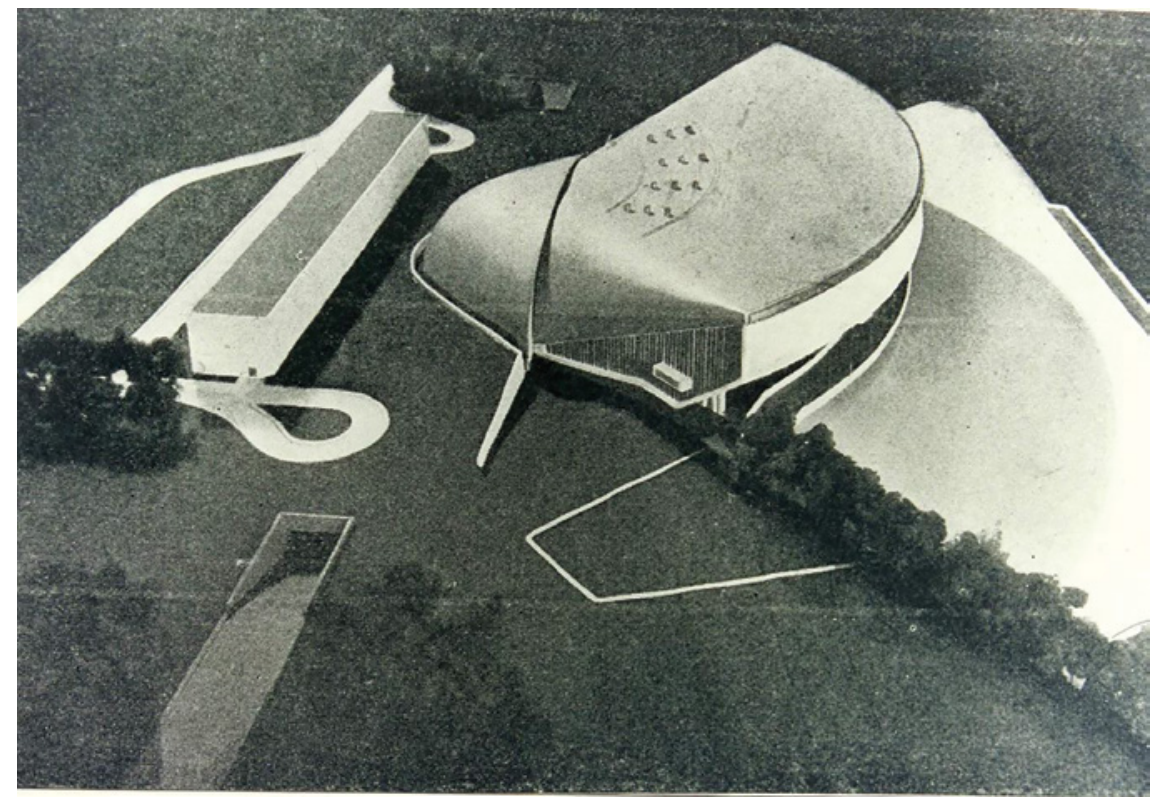

Figure 2 E. Catalano, R. Nery, R.O. Greco, F.E. Lanús, F. Degiorgi, A. González Gandolfi, Buenos Aires Auditorium.

SOURCE: REVISTA DE ARQUITECTURA, SOCIEDAD CENTRAL DE ARQUITECTOS, JUNIO DE 1948

32 On FORJA see Miguel Ángel Scenna, FORJA: Una aventura argentina (Buenos Aires: Universidad de Belgrano, 1983); Christian Buckrucker, Nacionalismo y peronismo: La Argentina en la crisis ideológica mundial (Buenos Aires: Sudamericana, 1987), 258-276; Ana Virginia Persello, El partido radical: Gobierno y oposición 1916-1943 (Buenos Aires: Siglo XXI, 2004). On formation of Peronist Party, see Moria Mackinnon, Los años formativos del Partido Peronista (1946-1950) (Buenos Aires: Siglo XXI, 2002). 
In this way, the position of Secretary of Public Works and Urban Planning went to Guillermo Borda, a former member of FORJA who, doing away in large part with existing bureaucracy, brought into the municipal structure an important team of modernist architects, who immediately began various housing complex projects (with the creation of the Housing Office), as well as a number of public buildings.

Of particular interest among these initial projects was the Buenos Aires Auditorium, designed by a team led by Eduardo Catalano. This was a hall for twenty thousand spectators (although its total capacity reached fifty thousand standing occupants), conceived as providing the cultural focal point in the central neighborhood of Palermo. This neighborhood is near the park originally destined for the upper social classes, but which had grown more broadly popular since the 1920s. For the project, Catalano's team planned to recover state lands that had been ceded decades earlier by the Sociedad Rural [Rural Society], a body that represented the country's important land-owners. In other words, representatives of the traditional political and economic elite (considered the 'oligarchy') were to be displaced in order to build a new meeting place for the masses. ${ }^{33}$ So political confrontation and the mark of Peronism were already present in the selection of this urban site.

An experimental project along the lines of modernist theater reform projects such as the Totaltheater of Walter Gropius and Erwin Piscator, the center was to consist of a great single hall, flexible and adaptable to all types of events or mass gatherings, a notion that challenged the specialized nature of conventional theatrical halls. ${ }^{34}$

The ... Auditorium ... is not intended to reproduce on a grand scale the expressions of the traditional intimate theater or auditorium. Rather, given its magnitude, the idea is to promote the rise of a new kind of spectacle, one based on the unlimited possibilities of electronic technology, especially with regards to lighting and sound amplification, as well as new concepts of space, scenery movement and integration of the arts.... The public relates to the interior and exterior spaces as well as to the show, which approaches spectators without conventional divisions.... The stage extends into the hall itself. ${ }^{35}$

'Dictamen de la Comisión', Boletín Municipal de la Ciudad de Buenos Aires 7794 (1946): 1734-1735.

'Architecture of the Peronist State 1943-1955', accessed February 26, 2018, http://architec tureperonism.tumblr.com/, fig. 5 .

'Auditorio de Buenos Aires,' Revista de Arquitectura 330 (1948): 168-181. 
The political context in which the work was planned, and the role of protagonist given to the public, worked as a kind of metaphor for the irruption of the masses, the 'people', into the nation's political space. The link between the people and theater had a distinct significance for Peronists, who often organized events for the masses, or other large political or union gatherings, in the main hall of the Colón Theater, whose primary purpose since its inauguration in 1908 had been opera and classical music, enjoyed in most part by the upper and middle classes.

The auditorium building functioned along these lines and suggested a new architecture that was unthinkable without a political and social context that was unprecedented for the country. We find here an articulation that is between the architectural vanguard and political populism, one that maximizes the transformational features of Peronism, emphasizing its novelty, seeing it as a radical rupture with the past.

The work, whose completion would have required large investments and posed major technical challenges, was never realized. Nevertheless, its architectural modernity led to other notable public municipal buildings in Buenos Aires, such as the Del Plata Market, the General San Martín Municipal Theater, and the various municipal fairs. Under its influence, the regional University of Tucumán brought into its Department of University Construction an outstanding team of modernist architects in 1948 under the direction of Jorge Vivanco. Among other works in the northwestern part of Argentina, this group was responsible for the Ciudad Universitaria [University Complex] in the Sierra San Javier, 30 kilometers (19 miles) from the provincial capital. This project was partially completed. Radical modernism was also prominent in architectural contests held in 1948 for public buildings in the city of San Juan, which had been destroyed by an earthquake four years earlier. ${ }^{36}$ Some recently created buildings that sought to emphasize the modernity of state action, such as the National Postal and Telecommunications Secretariat (1949), adopted this kind of language. ${ }^{37}$

In the sphere of urban planning, radical modernist proposals were also put forward. In the City of Buenos Aires, new technical possibilities and policy coincided in the claim for the beginning of the 'planning age' by declaring a confrontation with a common enemy that acted in both economics and urban

36 On San Juan, see Healey, The Ruins of the New Argentina.

37 On modernism, see Sondereguer, Arquitectura y Modernidad en la Argentina; Liernur, Arquitectura en la Argentina del siglo XX., 229-269; Aboy, Viviendas para el pueblo. 
development: liberalism. ${ }^{38}$ The city government prolonged interventionist measures that had been implemented by the June Revolution, such as the new Building Code and a rent freeze. In 1947, the government created the Estudio para el Plan de Buenos Aires [e PBA: Study for the Plan of Buenos Aires] as a planning organ for the city, which replaced the previous Office of Urban Planning that had functioned between 1930 and $1943 .{ }^{39}$

Leading this new department was a Le Corbusier disciple, Jorge Ferrari Hardoy, who along with Juan Kurchan, his colleague from the group Austral, had elaborated an urban plan for Buenos Aires in 1938 in Le Corbusier's study in Paris and under his direction. ${ }^{40}$ In 1939, they had tried without success to interest the conservative government in developing the plan. The Peronist city government, however, given their modernizing and planning policies, incorporated it into the state structure.

The 1938 plan-a very ambitious one, since it followed the urban-planning principles of the International Congress of Modern Architecture (CIAM) consisted of a radical transformation of the city that would be undertaken in phases or in a gradual manner. ${ }^{41}$ Its main goal was to make the city more concentrated by restructuring the urban fabric through high-density residential areas. This would reduce the city's spread, with a tendency to retain its traditional center, while the neighborhoods of Belgrano and Flores would remain as 'satellite nuclei'. Lands freed of construction by this concentrating process would be converted to green spaces and cultivation. A network of new traffic ways that respected existing routes would channel traffic between the city and the metropolitan area that surrounded it. The plan also called for

38 'Discurso del intendente Siri al nombrar en sus cargos a los consejeros del E PBA,' Revista de Información Municipal 87-89 (1948): 9-12.

39 Decreto municipal no. 10.989/1947.

40 Austral was a group of young modernist architects formed in 1937 and active (as a collective formation) until 1941, considered by the History of Argentine Architecture as the beginning of a true architectural avant-garde, for its communication strategies, its radicalized modernist aesthetic and its critical position with traditional educational institutions in architecture. The name that identified it, Austral [Southern], referred to the geographical position of Argentina and expressed a willingness to participate in international aesthetic and urbanistic debates while contemplating local problems and conditions. Jorge Francisco Liernur con Pablo Pschepiurca, La red austral: Obras y proyectos de Le Corbusiery sus discípulos en la Argentina (1924-1965) (Buenos Aires: Universidad Nacional de Quilmes / Prometeo 3010, 2008).

41 'Architecture of the Peronist State 1943-1955', accessed February 26, 2018, http://architec tureperonism.tumblr.com/ figs. 6-7. A description of the plan can be found in the issue dedicated of La Arquitectura de Hoy 4 (1947). 
great complexes of public buildings, examples of which are both national and municipal government centers, as well as a centre for unions and another for private administration (the cité des affaires, in Le Corbusian terms). It proposed recovering the relationship between the city and the river, replacing the old port along the coast with green and recreational spaces and building an artificial platform on which would be located the skyscrapers of the cité des affaires. Skyscrapers on the river comprised the main image of the plan, and this was what most interested Le Corbusier.

However, the political period during which this plan became part of the sphere of the state was to have a strong effect on it, and its creators found themselves obliged to adapt it to the new Peronist policies, the main concern of which was the need to provide public housing. As an exemplifying operation that would demonstrate the benefits of the plan, the project team designed a complex of high-density super-housing-blocks for fifty thousand residents in a depressed area. This was the so-called Urbanización del Bajo Belgrano [Lower Belgrano Development]. 'In this neighborhood is found the seed ... of a large

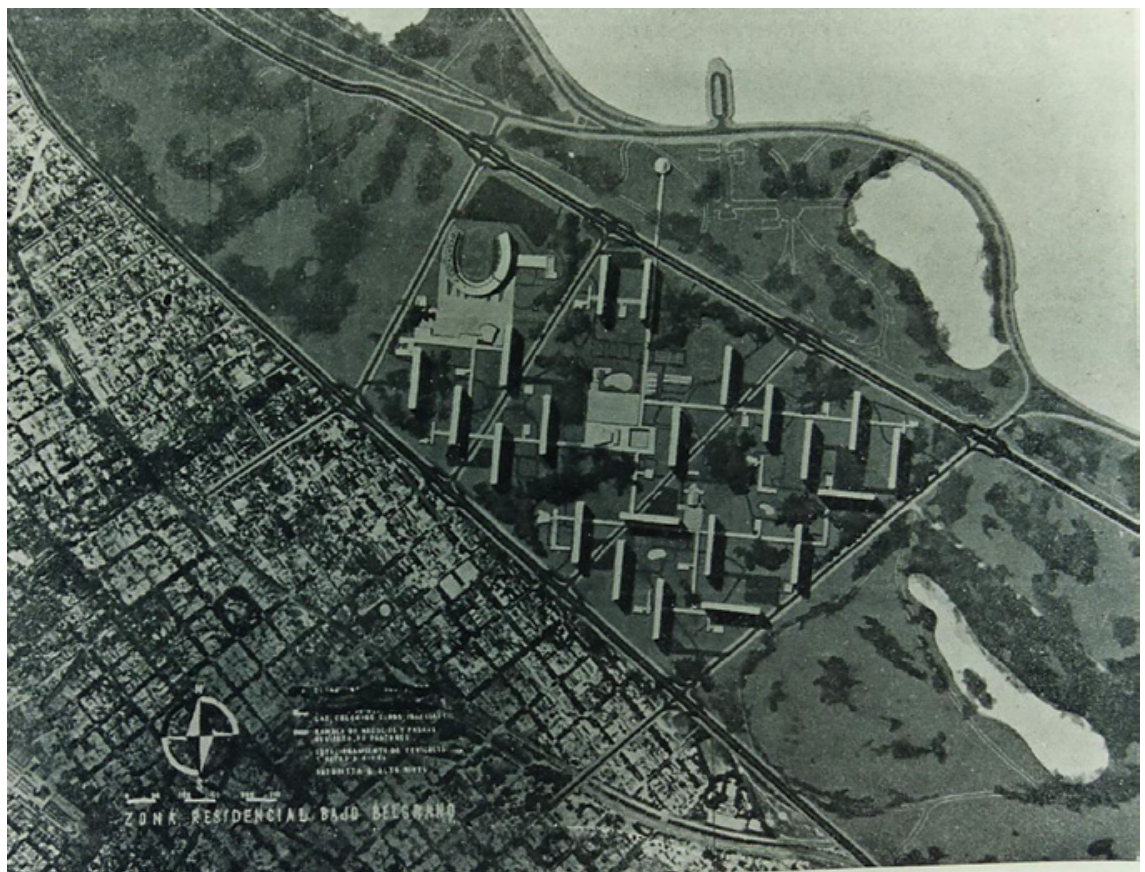

FIGURE 3 EPBA (Estudio para el Plan de Buenos Aires), Proyecto Urbanización del Bajo Belgrano (Lower Belgrano Development). SOURCE: REVISTA DE ARQUITECTURA, SOCIEDAD CENTRAL DE ARQUITECTOS $\mathrm{N}^{\circ} 329(1953)$ 
part of the proposals which will later drive the plan for the entire city'. Plan pamphlets spoke of 'the founding of a new Buenos Aires', emphasizing the new and radical transformation of the urban fabric that was foreseen. ${ }^{42}$

So the plan was adapted to local political conditions: Le Corbusier's office high-rises became housing high-rises. The city-scaping theme encompassing the relationship between the new city and the river was maintained, but in a way that synthesized the modernizing-populist tendencies of Peronist policy. Although this was a proposal for radical transformation, the plan's intent was to link to local urban traditions, especially the tradition of the barrio, the neighborhood, as the organizer of the city. The populations of existing neighborhoods in the city were used as a reference for the number of dwellings projected, and a 'recovery of the traditional Latin function of the square as the center of relational life' was attempted through the incorporation of 'a grand civic esplanade at the center of the complex.' ${ }^{43}$ These were all new elements that were far from casting this modernist urban planning in the known die of the "tabula rasa" with which it was frequently associated. The attempts to incorporate the plan into the state and articulate it with other policies were the key reasons for these modifications to the original 1938 design, and point once again to the desire to reconcile the familiar and traditional with modernist ambitions of radical renewal.

Although work on the project began and one of the blocks was built, political disagreement between the central and municipal governments led to Mayor Siri's resignation in 1949, which was followed by the distancing of members of his cabinet. The EPBA did not disappear, but it lost priority and clout within the municipal structure. A few years later, between 1952 and 1954, which saw the beginning of the second administration of Perón, an architect member of the regime was named Mayor: Jorge Sabaté, who had a distinguished professional career. Sabaté carried forward the dream of a modernist city, but channelled it through more modest architectural proposals than those undertaken in the initial period of the administration. Once again it can be seen how an ethos of pluralism persisted in post-war Argentina under a Peronist regime that could never develop into an authoritarian government with centralized state powers comparable to those of the fascist or Soviet regimes. As a result, architectural schemes which were excessively radical in scope or aesthetic concept could not be brought to fruition.

\footnotetext{
42 EPBA, $3^{\circ}$ Fundación de Buenos Aires (Buenos Aires: Municipalidad de Buenos Aires, 1948). 'Architecture of the Peronist State 1943-1955', accessed February 26, 2018, http://architec tureperonism.tumblr.com/ fig. 9-10.

43 'Urbanización del Bajo Belgrano,' Revista de Arquitectura 329 (1953): 23.
} 


\section{Classicist Notes: Eva Perón and Her Images}

Officially created in 1948 through the action of its president, The Eva Perón Foundation, constituted, according to Mariano Plotkin, a veritable 'state within the state. ${ }^{44}$ Strictly speaking, it was a private institution within the non-state, public sphere, led by the First Lady, and its purpose was to provide 'social assistance' to those who fell outside of the state or union assistance apparatus. It had a precedent in the Sociedad de Beneficencia [Charitable Society], founded in 1823, and in 1948 dissolved and incorporated into the recently formed Dirección Nacional de Asistencia Social [National Office of Social Assistance]. That society had been comprised of women from the social elite (the 'oligarchy'), and its presidency was always honorarily bestowed upon the First Lady. It had undertaken social assistance activities and built

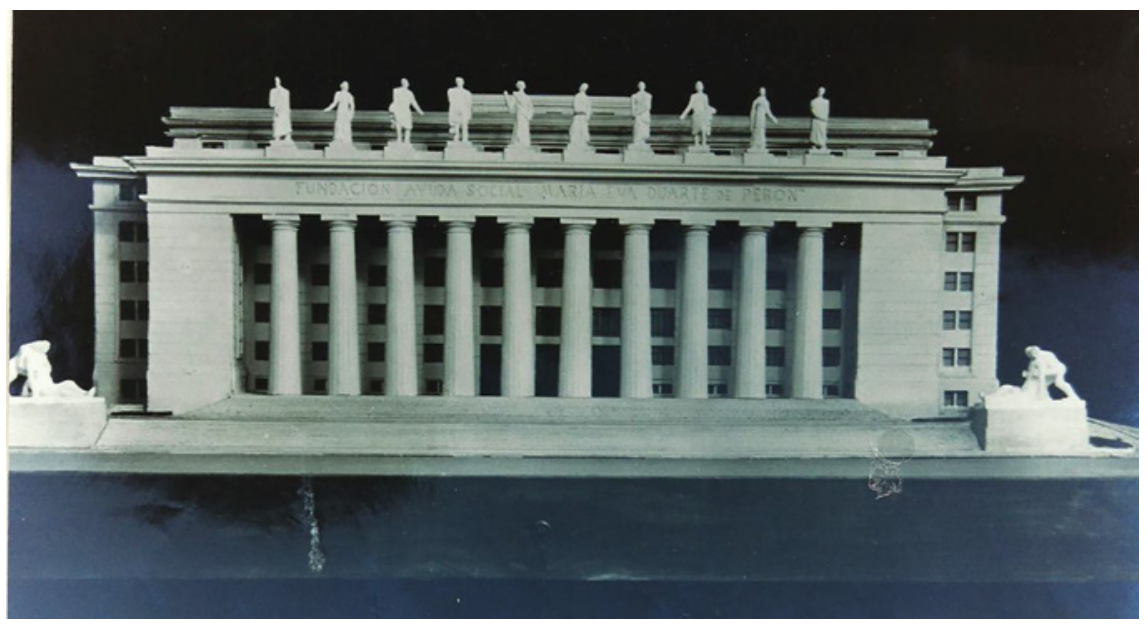

FIgure 4 Eva Perón Foundation Headquaters.

SOURCE: ARCHIVO GENERAL DE LA NACIÓN, SECCIÓN DOCUMENTOS GRÁFICOS

44 Mariano Plotkin, Mañana es San Perón (Buenos Aires: Ariel, 1993) 215. The institution was created under the name of the Fundación de Ayuda Social María Eva Duarte de Perón [María Eva Duarte de Perón Foundation for Social Assistance], which was simplified in 1950 to the Fundación Eva Perón [Eva Perón Foundation]. Eva's social assistance activity had begun in 1946 with food distribution efforts. See also, Néstor Ferioli, La Fundación Eva Perón (Buenos Aires: Centro Editor de América Latina, 1990); Martín Esteban Stawski, Asistencia social y buenos negocios: La política de la Fundación Eva Perón 1948-1955 (Buenos Aires: Imago mundi, 2009); Carolina Barry, Karina Ramacciotti and Adriana Valobra, La Fundación Eva Perón, entre la provocación y la inclusión (Buenos Aires: Biblos, 2008). 
and managed shelters, educational establishments and hospitals. In fact, the Eva Perón Foundation renewed and enlarged social assistance programs previously handled by the Society, although there was an enormous difference between the two institutions. Indeed, the Foundation was closely associated with national policies and saw growth under the political leadership of Eva Perón, becoming the 'long arm of the regime', ${ }^{45}$ while the Society had lacked any political affiliation. The Foundation received state funds that came from workers' salaries and private donations. 'Upon Eva's death in 1952 ... it had become an extremely powerful institution that moved enormous sums of money without any type of control'.46

From an architectural point of view, the Foundation's production had at least two sides: that of buildings dedicated to social programs (1947-1955) which adopted the aforementioned California Style, ${ }^{47}$ and that of its headquarters

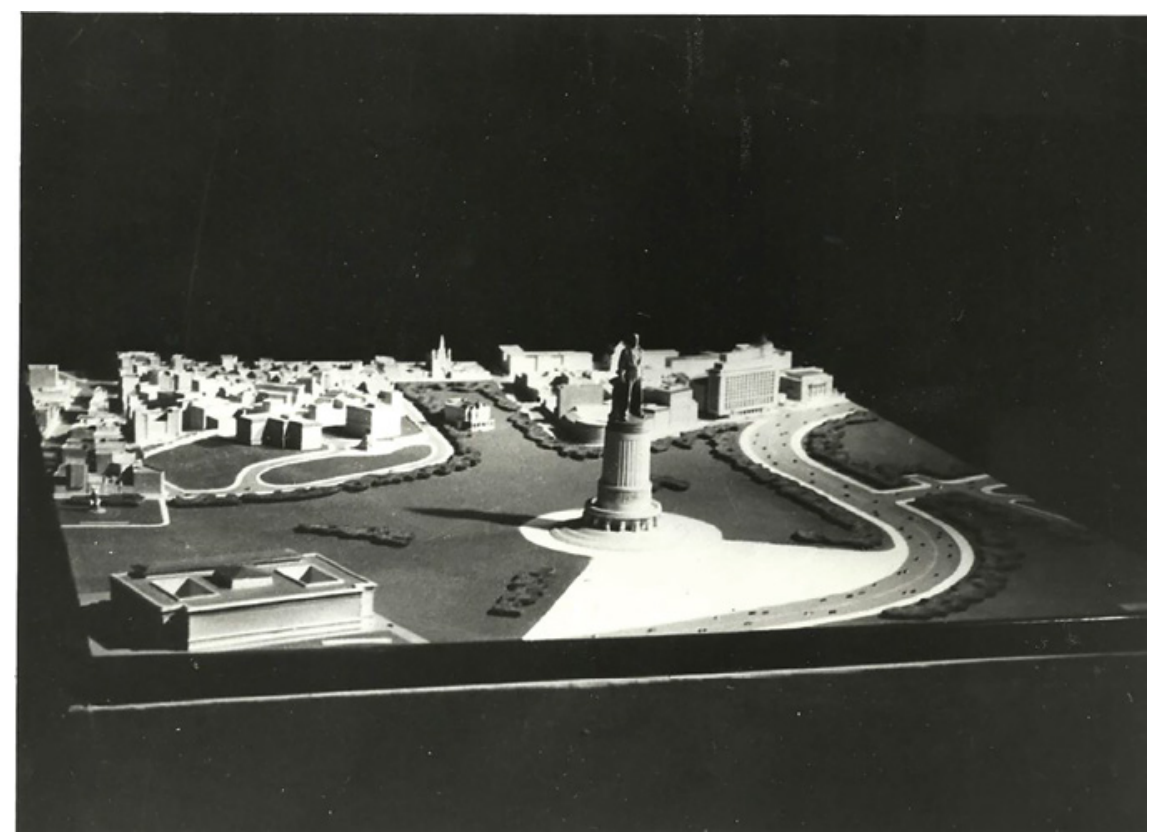

FIgURE 5 Eva Perón Monument.

SOURCE: ARCHIVO GENERAL DE LA NACIÓN. SECCIÓN DOCUMENTOS GRÁFICOS

\footnotetext{
45 Plotkin, Mañana es San Perón, 215.

46 Ibid.

47 'Architecture of the Peronist State 1943-1955', accessed February 26, 2018, http://architec tureperonism.tumblr.com/ fig. 11.
} 
(1950), which had a very particular, stripped classicist style. Finally mention must be made of the mausoleum-monument constructed in her memory (1952-1955, figs. 14-15), in which classicist forms are again present. (Although it was built by the state rather than the Foundation, this project's strong connection to Eva Perón's political myth makes it necessary for us to include it in this set.)

It is important to emphasize that the Foundation's production included works that are modernist from an aesthetic point of view, such as the La Plata University Refectory or the Santa Fe Polyclinic, although these projects were undertaken after Eva's death, an event that dealt a significant blow to further development of its activities. ${ }^{48}$

Among the Foundation's social programs the so-called home schools stand out. In addition to education, these establishments provided shelter by boarding students. They were referred to as "cities" and differentiated from one another by their educational levels. Two of them were built in Buenos Aires: the Ciudad Infantil [Children's City], a home school dedicated to pre-school children, and the Ciudad Estudiantil [Students' City], for youngsters in secondary school. These are located in the neighborhood of Belgrano near the plot of land on which the EPBA had planned to build the Urbanización del Bajo Belgrano [Lower Belgrano Development], complex mentioned in the previous section.

Like other works promoted by the Foundation, both of these were privileged objects in terms of state propaganda, the responsibility of the Secretary of Information. Images of the California Style, strongly associated with domestic life, worked symbolically as expressions of the 'love' that Eva Perón manifested feeling for her people and the warm link, protective and maternal, that she established with them. Also, the presentation to the working class of such images, earlier associated with upper-and middle-class leisure, lent them a character that might be called 'redistributive', if we apply this term-one that Peronism used to refer to the materialistic world - to the area of symbolism. According to the magazine Mundo Peronista [Peronist World], the young residents of Students' City affirmed that they lived like kings'49 This meant that, thanks to the love of Eva Perón, they could now enjoy spaces and images from which they had previously been excluded. This worked like a promise of wellbeing and happiness; the search for symbols of 'social justice' was reiterated in different ways in the architectural production of Peronism. In her study on the

48 A panorama of the Foundation's architectural production can be found in Revista de Arquitectura 370 (1953).

49 'Esta obra de amor,' Mundo Peronista 24 (1952): 28-30. 
representations of workers in the graphics of the period, Marcela Gené, offers the expression 'A Happy World', and this can also be applied to scenes created by the Foundation for its social programs. ${ }^{50}$

One different image is that presented by the Foundation's headquarters. This building was promoted with the aim of bringing together administrative technical offices, which had been distributed among different buildings in the city center. The new building also included areas for attention to the public and medical offices. The headquarters was located in a working-class area on the city's south side, across the street from that of the Confederación Nacional del Trabajo [CGT: National Labor Confederation], a building which the Foundation had donated some years earlier. In political terms, the proximity of these two buildings, one belonging to organized labor and the other to the social assistance efforts of Eva Perón, was a statement of the political alliance established to a great extent by the Peronist powers. The Foundation's headquarters building was nearing its inauguration when the Peronist government fell in 1955, and so its original purpose was never realized. ${ }^{51}$

From an architectural point of view, the building took as a reference a work constructed during the period, but one which had been planned earlier: the School of Law of the University of Buenos Aires (1938). ${ }^{52}$ The architecture of both buildings integrates the domain of so-called stripped classicism, a tendency that developed in the 1930s, not only in countries ruled by dictatorships but also in countries with democratic régimes such as the United States during the New Deal. ${ }^{53}$ In all those cases it had the intention of creating images of national affirmation and of a strong State, although it was much less frequent to have it refer directly to a political leader, as in the case of Argentina. In addition, the different timing (1938 as opposed to 1950) made a great difference: the Foundation headquarters building is a very late example of classicism.

However, since this is a large topic, it is necessary to clarify some important points, especially with regards to the Foundation headquarters building. As an architectural aesthetic, stripped classicism, as we know, combines forms and types of composition from the classical tradition and makes them

50 Marcela Gené, Un mundo feliz: Imágenes de los trabajadores en el primer peronismo, 1946-1955 (Buenos Aires: Fondo de Cultura Económica, 2004).

51 After the fall of Peronism, the building was devoted to housing the School of Engineering of the University of Buenos Aires, as it does to this day.

52 'Architecture of the Peronist State 1943-1955', accessed February 26, 2018, http://architec tureperonism.tumblr.com/ fig. 13 .

53 Giorgio Ciucci, 'Linguacci clasicisti negli anni trenta in Europa e in America,' Maurizio Vaudagna, ed., L'estetica della política: Europa e America negli anni trenta (Bari: Laterza, 1989), 45-57. 
more abstract, primarily by reducing decoration. In other words, classicism is modernized by purging its formal repertory. Although this description characterizes the building in general terms, it is necessary to point out that it does not completely cover two of its features, and so in order to appreciate these, we must mention some particular nuances.

The first feature consists of the fact that channels are maintained in the shafts of the façade columns. This, along with the presence of the capital, lets us recognize an order: the baseless Doric, while the majority of buildings of this type of architecture have modern, smooth-surfaced columns, doing away with the figurative elements of the language of classicism. So these channels reinforce the classicist character of the building. The second feature is the presence of large sculptures on the crown of the façade (in the manner of renaissance buildings of Italy's Veneto), which are not present on the Faculty of Law building. The work of the Italian Leone Tommasi, these sculptures are traditional and represent personages from Argentine history (General José de San Martín, considered the founding father) and allegorical figures (such as Justice), or they evoke the beneficiaries of social action (the figure of a worker). So an iconographic program is incorporated here, a detail not common to Peronist state buildings.

These two features reinforce the classicist character and the rhetorical capacity of the building. In terms of symbolism, they emphasize classicism's symbolic values of universality and eternity, which appear to be transferred to the political leadership of Eva Perón herself. In this case, the architectural images do not evoke love or social justice, as the architecture of the Foundation's social programs did, rather they appeared to refer to the timelessnessthat is, the eternity — of a political leadership that had won its place in the nation's history, a function that has parallels, in muted form, with the 'immortalizing' function of stripped classicism in Nazi civic buildings explored by Roger Griffin in this issue of the Fascism journal. ${ }^{54}$

'Love' and 'eternity' work as complementary representations, the symbolic reading of which is amplified in the last work dedicated to Eva Perón: the mausoleum-monument-another Tommasi work - that the National Congress decided in favor of erecting in her memory in 1952. ${ }^{55}$ Construction on it began in 1954 but was abandoned with the overthrow of the government a year later.

54 Roger Griffin, 'Building the Visible Immortality of the Nation: The Centrality of "Rooted Modernism” to the Third Reich's Architectural New Order', Fascism: Journal of Comparative Fascist Studies 7 (2018): 8-43.

55 Ley 14.124/1952. 
Located near the shore of the river in the northern part of the city, the monument faced the presidential residence: the living leader reaffirmed his presence through the evocation of his deceased wife and political companion. It consisted of a 137-meter (450-foot) column with the mausoleum located in its base. ${ }^{56}$ The column supported a colossal figure of a descamisado [shirtless one], the term adopted in Argentina to refer to the 'new man'. This was a theme common to the political culture of diverse countries in Europe, as well as in the United States between 1930 and $1945 .{ }^{57}$ As in the United States, the Argentine 'new man' was a worker, his dress and the presence of a traditional tool, the anvil, composed a conventional and timeless image: an allegory of labor.

A notable fact about the monument is that it did not pay direct homage to Eva Perón through a representation of her, but rather indirectly through the figure of a worker. As the sculptor stated, the female body of Eva would have had to be sculpted in marble, and this was not feasible due to the colossal dimensions he wished to use. Nevertheless, we should not deny the possibility that this choice was due as well to other factors. The first is that the construction of a monument to the descamisado had been pending for years, under a national law of 1946. Such a monument had been planned on numerous occasions but always postponed, and therefore the combination of both ideas would resolve this issue. The second factor becomes obvious when we look at the iconographic program of the Foundation's headquarters building and its proximity to that of the $C G T$. We might think indeed that the close relationship between Eva and the workers was one of the public perceptions that founded the political myth around her: she and her people comprised a unit, one image referring to the other.

As is true with New York's Statue of Liberty, it would have been possible for people to circulate in the interior of this colossus. Also, the gigantic figure dominated the skyline and-again like the Statue of Liberty-entered the field of vision of those who approached the city from the river. The Dean of the School of Architecture and Urban Planning, Manuel A. Domínguez, interpreted this new political landscape in this way: 'Future travellers ... will see in the distance a bronze colossus, bare-chested, grave and sure beside the anvil where injustice has been smashed and the happiness of the Argentine people

$5^{6}$ 'Architecture of the Peronist State 1943-1955', accessed February 26, 2018, http://architec tureperonism.tumblr.com/ fig. 14.

57 Giorgio Ciucci, 'Linguaggi classicisti negli anni Trenta in Europa e in America,' in L'estetica della política: Europa e America negli anni Trenta, ed. Maurizio Vaudagna (Bari: Laterza, 1989), 45-57. 
and the greatness of the nation have been forged. And they will wonder, "What nation is this that raises a monument of this magnitude, free of trophies and bellicose allegories, where all is a song to dignity and human solidarity?"'58

It is worth highlighting, by way of conclusion, that the aesthetic monumentality found in architectural images associated with the figure of Eva Perón did not have equivalents in the architectural production of Peronism. Strictly speaking, in quantitative terms, it represents a very small fraction of the public buildings of the period, and moreover, these buildings were constructed during the second Perón government, when the authoritarianism of the regime and the personality cult around him became more accentuated. It is undoubtable that the singularity of works undertaken, as well as of their close relationship with the political leadership, made for images of monumentality that took on extreme symbolic weight in the Peronist collective imagination. Nevertheless, these works cannot eclipse a state architectural production that was much broader and that developed in other directions.

\section{Conclusions}

Within the context of Peronist expectations regarding culture, we have examined here three cases of architectural and urban intervention that displayed various kinds of articulation in terms of promotional policies, state institutions, intervening technology, the urban aspects involved, and the architectural aesthetics proposed. The suburban project of Ezeiza, the plan for a radical transformation of Buenos Aires, and architecture associated with Eva Perón demonstrate the diversity of types of action developed within the state. These were the result of the presence of the various distinct technical teams at work within that state and the impossibility of imposing a single direction, or even general guidelines.

In all cases, we can interpret the works-in terms of their forms and images and the political content they transmit-as materializations of the new order driven by Peronism. Each of the cases highlights different visualizations or aspects of this new order: the balance of the organized community (Ezeiza), the drive and revolutionary transforming capacity of the new political force (the Plan of Buenos Aires), or the communion maintained by the leader and her people (Eva Perón).

$5^{8} \quad$ Boletín de la Facultad de Arquitectura y Urbanismo 4 (1953): 7. 
We have analysed the links between architecture and policy in terms of their tangential nature, identifying the characteristics and the conditions of their contact, one that has been profoundly significant for both areas. This is true for politics because in architecture is found a materialization of political ideas, an instrument for transforming the city and society and the images with which these are identified. And it is true for architecture because particular demands modify characteristics forged by previous history. Indeed, we have seen that each of the projects underwent obvious transformations once it came in contact with the new political reality.

Finally, in each of the cases we have found hybrid architectural groups: a combination of rustic and modernist forms in Ezeiza, radical modernism that was adapted to local conditions in the Plan of Buenos Aires, and rustic, classical, and monumental forms in the case of Eva Perón. However, it is worth emphasizing that political propaganda favored the diffusion of rustic (California Style) forms to such an extent that these appear to have endured in the political collective imagination as 'Peronist architecture'. Two reasons can be given for the tendency to favor this aesthetic. First is the central importance of populism in Peronist political ideology. Second is the association of this aesthetic with the social programs promoted by Eva Perón, herself a prominent figure in the political propaganda of the period.

In conceptual terms, all of the characteristics mentioned here relative to Peronist production were also observable in the projects of inter-war dictatorships, especially those of Italian Fascism. Moreover, it has been pointed out that, given the period in which Peronism came to power, and due as well to the characteristics of the political period in which it was active, it cannot be accurately defined within the political categories of 'interwar dictatorship' or even 'fascism'.

Nevertheless, if we avoid pedantry and literal-mindedness in applying these two categories, we can say that the work of Peronism falls within the fascist era in terms of ethos if not chronology, due to its promotion of projects marked by ambition and vision, commissioned or facilitated through the power of the state, and conceived in a spirit of comprehensive national modernization and populist optimism for the future. Such projects elevated Perón and Eva to the level of leaders of the people, whom they saw as an organic entity, socially harmonious, rooted in the history of the nation and, in international terms, decidedly on the road to the 'third position'. This strategy was supposed to keep communism at bay while symbolically counteracting the anarchy and atomization of liberal democracy and liberal capitalism through the creation of a planned built environment fulfilling national and social goal, while serving a 
communal cultural function decided from above by an enlightened leadership. The simultaneous embrace of continuity with the past and of an imaginatively, heroically modern future under Peronism produced a variety of aesthetics which resonated with the 'rooted modernism' pioneered in different ways under by Fascism and Nazism in the previous two decades. 